\title{
Water Productivity Improvement Using Water Saving Technologies in Boro Rice Cultivation
}

\author{
M B Hossain ${ }^{1 *}$, D Roy², P L C Paul² and M T Islam³
}

\begin{abstract}
An experiment was conducted at farmers' field aimed to evaluate the water saving technologies in Boro rice. The experiment involved three plots at $33 \mathrm{~m}, 65 \mathrm{~m}$ and $100 \mathrm{~m}$ distance from the water source. Each plot was divided into two parts to accommodate two management practices as research management (RM) and farmer's management (FM). RM comprised of plastic pipe water distribution system to reduce conveyance loss and alternate wetting and drying (AWD) method for field water management. FM comprised of earthen canal water distribution system and conventional irrigation method. BRRI dhan28 was cultivated with recommended agronomic practices. In RM, irrigation was applied when water level went $15 \mathrm{~cm}$ down below the ground surface where FM included conventional practice. Result showed that conveyance loss of water in earthen canal increased with increasing the distance from water source to field. Conveyance loss found 6.1 and $0.5 \mathrm{l} \mathrm{s}^{-1}$ per $100 \mathrm{~m}$ in earthen canal and plastic pipe distribution system, respectively. Plastic pipe distribution system successfully minimized $91.6 \%$ water loss that occurred in earthen canal. AWD practice alone saved $20.2 \%$ field water over conventional practice. Combination of AWD and plastic pipe had saved $42 \%$ water, Tk 2,270 ha- $\mathrm{ha}^{-1}$ electricity cost and Tk 2,947 ha-1 as irrigation cost over farmer's management. RM had higher yield than FM due to better performance of yield contributing parameters. Water productivity increased from $0.35 \mathrm{~kg} \mathrm{~m}^{-3}$ in FM to $0.65 \mathrm{~kg} \mathrm{~m}^{-3}$ in RM. Both the technologies in RM are environment friendly for reducing groundwater use in the irrigated ecosystem.
\end{abstract}

Key words: Alternate wetting and drying, conveyance loss, distribution system, water productivity

\section{INTRODUCTION}

Agriculture is the major water user, accounting for about $70 \%$ of the world's freshwater withdrawals and over $40 \%$ of OECD countries' total water withdrawals (OECD, 2010). Water shortage is very high in south-west and north-west regions of Bangladesh during the dry season due to low annual rainfall. The demand for both surface and groundwater for irrigation is on the rise in the dry winter season and amounts to 58.6 percent of the total demand for water $(\mathrm{GoB}$, 2005). The principal crop during this season is Boro rice, which is 70 percent of the total crop production of Bangladesh (GoB, 2005). Moreover, it requires more water in the production process than either wheat or potato. Biswas and Mandal (1993) estimates that water requirements are $11,500 \mathrm{~m}^{3}$ per hectare (ha) of Boro rice. A huge amount of water is misused by keeping continuous ponding condition in rice plots during Boro season in the irrigation projects as well in farmer's management in both major and minor irrigation systems of Bangladesh (Sattar et al., 2009). Due to huge water loss, comparatively less area than potential is irrigated with this huge amount of water. Irrigation water is a critical factor for crop production in Bangladesh, which can make a crop either a success or a failure (Rashid et al., 2005). The rainfall is not evenly distributed throughout the year. About 95 percent of the total rainfall occurs during April to October, leaving the remaining five months of the year essentially dry (Rashid et al., 2005). During Rabi season, from November to March, 
rainfall is only $5 \%$ of the annual total. This amount is inadequate and results in low production (Huq et al., 1992). A rice crop cannot be sustained during this period from rainfall alone and is fully dependent on irrigation (Rashid et al., 2005). In Bangladesh, the heavy use of groundwater has led to shallow wells falling dry by the end of the dry season and to severe problems of arsenic pollution in rice-growing areas (Ahmed et al., 2004). Geethalakshmi et al. (2011), reported that about 3,000-5,000 liter of water input is required in rice field to produce $1 \mathrm{~kg}$ of rice depending on different rice cultivation methods. Irrigated rice makes the highest demand of water in agriculture sector. Currently, on-farm availability of fresh water is reducing due to many reasons (Uphoff, 2006). Future predictions indicate that two million hectare of fully irrigated and 13 million hectare of partially irrigated lands in Asia during wet season would experience a 'physical water scarcity' and 22 million hectare of irrigated lands in the dry season would face 'economic water scarcity' by 2025 (Tuong and Bouman, 2003).

Water conveyance loss consists mainly of operation losses, evaporation and seepage into the soil from the sloping surfaces and bed of the canal. The most important one of them is seepage. The seepage loss in the irrigation canals accounts for the major portion of water conveyance loss (98.37\%) while approximately 0.3 percent of the total stream is lost due to evaporation (Akkuzu et al., 2006). Major or minor irrigation projects of

Bangladesh get water loss about 30 to 40 percent of total applied through the earthen channels at the time of distribution (Satter, 2004). Improper design, poor management of the canal, insufficient freeboard and socialconflicts are the factors affecting conveyance loss. The recent BRRI (2007) findings indicate that $95 \%$ of total conveyance loss in earthen canal can be minimized by adopting plastic pipe distribution system in STW. Beside this, it can reduce the irrigation time by about $50 \%$ resulted in reduced fuel, oil, irrigation cost, labour cost and also 45\% command area can be increased by using plastic pipe distribution system (Sattar et al., 2009).

Alternate wetting and drying (AWD) is a matured technology, which successfully saved irrigation water in rice filed. By applying AWD, farmers or pump-owners are able to save 15 to $30 \%$ of their irrigation water (Bouman et al., 2007). AWD practice enables farmers to save irrigation water by $25-50 \%$ and also getting higher yields and more profits than conventional rice production (CRP) (Uphoff, 2006). Experts state that on a national level, the implementation of AWD could save costs for irrigation of up to 56.4 million Euros in electricity or 78.8 million Euros in fuel (30 liter diesel ha-1) (GoB, 2005). The above discussion will necessitate and encourage research on alternative measures for reducing water use and increasing the efficiency of water use in order to ensure food security. With decreasing water availability for agriculture and increasing demand for rice, water use in rice production systems need to reduce and water productivity to increase. Individually i.e. distribution system and field water loss for Boro rice production may be studied by many researchers. But the combined effect of distribution system and field water management is lacking. Therefore, this study was undertaken to increase water productivity through improved water saving technologies in Boro rice cultivation.

\section{MATERIALS AND METHODS}

An experiment was conducted at farmers' field in Kushtia, Bangladesh during Boro 2013-14. Soil type of the experimental field was silt loam. Experimental area belongs to AEZ-11 (High Ganges river flood plain) with mean annual rainfall 1,478 $\mathrm{mm}$ (BRRI, 2014). The experiment involved three plots at $33 \mathrm{~m}$, $65 \mathrm{~m}$ and $100 \mathrm{~m}$ distance from water source. 
Each plot divided into two parts. One part was under research management (RM) and another part was under farmer's management (FM). The variety was BRRI dhan28 and 42days old @ 2-3 seedlings were transplanted with $20 \mathrm{~cm} \times 15 \mathrm{~cm}$ spacing. BRRI recommended fertilizer doses and cultural practices were applied during the season. The whole amount of $\mathrm{P}, \mathrm{K}, \mathrm{S}$ and $\mathrm{Zn}$ fertilizer was applied as basal dose during land preparation. Urea was top-dressed in three equal splits at $15 \mathrm{DAT}, 30 \mathrm{DAT}$ and $40 \mathrm{DAT}$. Herbicide was applied after five days of transplanting. Furthermore weeding and spraying were done to control weed and insect pests. Rice yield was assessed taking samples from 10 square meter area of each plot and collected yield parameters. Finally, the yield was adjusted to $14 \%$ moisture content to determine yield per hectare. Data were analyzed using Cropstat 7.2 version.

\section{Management practices}

RM plot included two management practices such as plastic pipe water distribution system followed by alternate wetting and drying (AWD) irrigation method. FM plot also had two management practices as earthen canal water distribution system followed by conventional irrigation method. Finally, water saving for RM was compared with FM. Besides water saving, cost of energy and irrigation were also calculated for both the management.

Conveyance loss management. Water was supplied to the RM plot through $12.7 \mathrm{~cm}$ diameter plastic pipe but in FM plot water was supplied through earthen canal. To measure conveyance loss for RM discharge was measured at the pump delivery point by using V-notch before installing plastic pipe and after installing plastic pipe discharge was measured at the outlet of plastic pipe using Vnotch. But for FM discharge was measured by installing $\mathrm{V}$-notch at inlet and outlet of the earthen canal. Thus the Conveyance loss was calculated using inflow-outflow method.
Conveyance loss was calculated with the formula following:

$$
S=\left\{\left(Q_{1}-Q_{2}\right) \div \mathrm{L}\right\} \times 100
$$

Where, $S=$ rate of conveyance loss in the canal $\left(\mathrm{m}^{3} \mathrm{~s}^{-1}\right.$ per $100 \mathrm{~m}$ distance), $\mathrm{Q}_{1}=$ rate of flow at the inlet $\left(\mathrm{m}^{3} \mathrm{~s}^{-1}\right), \mathrm{Q}_{2}=$ rate of flow at the outlet $\left(\mathrm{m}^{3} \mathrm{~s}^{-1}\right), \mathrm{L}=$ distance between two points $(\mathrm{m})$

Field water management. Alternate wetting and drying method was followed in RM after 15 days of transplanting. A $10 \mathrm{~cm}$ diameter and $25 \mathrm{~cm}$ long perforated $(15 \mathrm{~cm})$ PVC pipe was installed at the corner of the plot having $10 \mathrm{~cm}$ above the ground surface and perforated $15 \mathrm{~cm}$ part was below the ground surface. Irrigation provided at $5 \mathrm{~cm}$ depth when water level went down $15 \mathrm{~cm}$ below the ground surface. This practice stopped only during one week before to one week after flowering stage and 2-3 cm standing water was maintained in this period. In case of FM, irrigation had been applied following conventional method. Usually farmers' don't follow definite irrigation schedule. Sometimes they applied irrigation when water disappeared from the field and sometimes maintained continuous standing water. Amount of water applied in both methods was recorded.

Discharge measurement. Discharge of the STW was measured using a $90^{\circ} \mathrm{V}$-notch weir, which is suitable to measure small flow accurately. The weir was placed across the canal at inlet and outlet of the canal. The following equation is used to calculate the rate of flow (Khurmi, 1997):

$$
\mathrm{Q}=1.417 \times \mathrm{H}^{5 / 2}
$$

Where, $\mathrm{Q}=$ discharge $\left(\mathrm{m}^{3} \mathrm{~s}^{-1}\right), \mathrm{H}=$ height of water above the apex of notch $(\mathrm{m})$

\section{RESULTS AND DISCUSSOIN}

Conveyance loss and its control measure using plastic pipe. Conveyance loss in earthen canal water distribution system (FM) found greater than plastic pipe distribution 
system (RM) (Table 1). Result shows that conveyance loss in FM varied with the length of distribution system. The conveyance loss in FM found $16.1 \%, 27.4 \%$ and $41.3 \%$ for the length of conveyance system $33 \mathrm{~m}, 65 \mathrm{~m}$ and $100 \mathrm{~m}$ respectively (Fig. 1). Water loss in this system occurs through seepage, percolation, over flow etc. Improper design of canal, poor management, insufficient freeboard etc are the main factors of the loss. This result is similar to Sayed (2010), who found $41 \%, 48 \%$ and $45 \%$ conveyance loss in earthen canal at Mithapukur, Manikganj sadar and Dhamrai respectively. Water loss in conveyance found 6.1 and $0.51 \mathrm{~s}^{-1}$ per $100 \mathrm{~m}$ in FM and RM respectively. Experiment reveals that conveyance loss had controlled successfully by $91.6 \%$ using plastic pipe distribution system (Table 1). This result is identical to Satter et al. (2009), who found in an experiment that $95 \%$ of total conveyance loss can be minimized by adopting plastic pipe distribution system in STW.

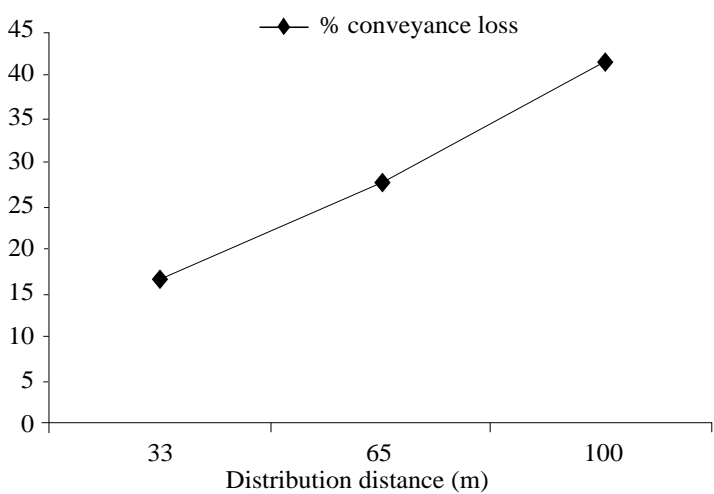

Fig. 1. Conveyance loss of water in earthen canal for different field distances from water source at Kushtia during Boro 2013-14.
Water saved by AWD method. Table 1 shows the number of irrigation and amount of water applied for both the treatments measured during the growing period. Result indicates that RM saved 4 numbers of irrigation over FM in case of BRRI dhan28. AWD method required 17 numbers of irrigation whereas conventional method received 21 numbers. About $104.6 \mathrm{~cm}$ irrigation water was applied in AWD method where $131.0 \mathrm{~cm}$ water in conventional method. RM saved $20.2 \%$ water over FM. This result is identical to Bouman et al. (2007) who reported that the AWD plots had the same yield as continuous flooding, but saved 16$24 \%$ in water costs and $20-25 \%$ in production costs.

Benefits of AWD and plastic pipe use. RM had great advantages over FM in terms of water, electricity and time saving. Combination of plastic pipe distribution and alternate wetting and drying method (RM) saved about $42 \%$ irrigation water than FM (Table 2). BRRI dhan28 produced 6.97 and $6.33 \mathrm{t} \mathrm{ha}^{-1}$ in RM and FM respectively. Yield increased in RM because of higher number of panicles as well as field grain and grain weight than FM. Water productivity of BRRI dhan28 under RM was $0.65 \mathrm{~kg} \mathrm{~m}^{-3}$ and under FM it was $0.35 \mathrm{~kg} \mathrm{~m}^{-3}$. Electricity consumption was found 1,394 and 819.4 kWh in FM and RM respectively. RM also saved Tk 2,270 ha-1 as electricity cost and Tk 2,947 ha-1 as irrigation cost over FM (Table 3).

Table 1. Conveyance loss measurement and field water used by different methods during Boro 2013-14.

\begin{tabular}{|c|c|c|c|c|c|c|c|}
\hline \multicolumn{4}{|c|}{ Conveyance loss management } & \multicolumn{4}{|c|}{ Field water management } \\
\hline $\begin{array}{c}\text { Management } \\
\text { practice }\end{array}$ & $\begin{array}{c}\text { Conveyance } \\
\text { loss } \\
1 \mathrm{~s}^{-1} \text { per } 100 \mathrm{~m}\end{array}$ & $\begin{array}{c}\% \\
\text { water } \\
\text { loss }\end{array}$ & $\begin{array}{c}\text { Conveyance } \\
\text { loss saved by } \\
\text { RM (\%) }\end{array}$ & $\begin{array}{c}\text { Management } \\
\text { practice }\end{array}$ & $\begin{array}{l}\text { Irrigation } \\
\text { (no.) }\end{array}$ & $\begin{array}{l}\text { Amount of } \\
\text { irrigation }(\mathrm{cm})\end{array}$ & $\begin{array}{c}\text { Field water } \\
\text { saved in } \\
\text { RM }(\%)\end{array}$ \\
\hline FM & 6.1 & 44 & & FM & 21 & 131.0 & \\
\hline RM & 0.5 & 3.7 & 91.6 & RM & 17 & 104.6 & 20.2 \\
\hline $\mathrm{LSD}_{0.05}$ & 1.03 & 8.54 & & $\mathrm{LSD}_{0.05}$ & & 17.7 & \\
\hline CV (\%) & 9.10 & 10.30 & & $\mathrm{CV}(\%)$ & & 4.3 & \\
\hline
\end{tabular}


Table 2. Total water used and water productivity of BRRI dhan28 in RM and FM during Boro 2013-14.

\begin{tabular}{lcccccc}
\hline Treatment & $\begin{array}{c}\text { Water } \\
\text { supplied cm) }\end{array}$ & $\begin{array}{c}\text { Water saved in } \\
\text { RM over FM }(\%)\end{array}$ & Panicle $\mathrm{m}^{-2}$ & $\begin{array}{c}\text { Filled grain } \\
\text { Panicle }^{-1}\end{array}$ & $\begin{array}{c}\text { Yield } \\
\left(\mathrm{t} \mathrm{ha}^{-1}\right)\end{array}$ & $\begin{array}{c}\text { Water productivity } \\
\mathrm{kg} \mathrm{m}^{-3}\end{array}$ \\
\hline FM & 184.9 & 42 & 423 & 96 & 6.33 & 0.35 \\
$\mathrm{RM}$ & 107.3 & & 406 & 117 & 6.97 & 0.65 \\
$\mathrm{LSD}_{0.05}$ & 52.6 & & 11.6 & 35.5 & 0.5 & 0.10 \\
$\mathrm{CV}(\%)$ & 10.4 & & 1.8 & 9.6 & 2.2 & 5.9 \\
\hline
\end{tabular}

Table 3. Electricity and irrigation costs in two management practices at Kusthia during Boro 2013-14.

\begin{tabular}{lcccccc}
\hline Treatment & $\begin{array}{c}\text { Time of } \\
\text { irrigation } \\
\left(\mathrm{hr} \mathrm{ha}^{-1}\right)\end{array}$ & $\begin{array}{c}\text { Electricity } \\
\text { consumed } \\
\left(\mathrm{kWh} \mathrm{ha}^{-1}\right)\end{array}$ & $\begin{array}{c}\text { Electricity cost } \\
\left.(\mathrm{Tk} \mathrm{ha})^{-1}\right)\end{array}$ & $\begin{array}{c}\text { Electricity cost } \\
\text { saved in RM } \\
\left(\mathrm{Tk} \mathrm{ha}^{-1}\right)\end{array}$ & $\begin{array}{c}\text { Cost of } \\
\text { irrigation } \\
\left(\mathrm{Tk} \mathrm{ha}^{-1}\right)\end{array}$ & $\begin{array}{c}\text { Irrigation cost } \\
\text { saved in RM } \\
\left(\mathrm{Tk} \mathrm{ha}^{-1}\right)\end{array}$ \\
\hline FM & 317.8 & 1394 & 5506.4 & 2270 & 22246 & 2947 \\
RM & 275.7 & 819.4 & 3236.4 & & 19299 & 29 \\
\hline
\end{tabular}

Electricity cost $=\mathrm{Tk} 3.95$ per unit, Irrigation cost $=\mathrm{Tk} 70 \mathrm{hr}^{-1}$.

\section{CONCLUSIONS}

Alternate wetting and drying method combined with plastic pipe water distribution system was found effective water saving technologies in Boro rice cultivation. Plastic pipe distribution system saved $91.6 \%$ water, which is lost as conveyance loss in earthen canal. AWD technique alone saved 20.2\% water (four irrigations) over conventional method. In combination of plastic pipe and AWD method saved $42 \%$ water with Tk 2270 ha-1 as electricity cost and irrigation cost of Tk 2947 ha $^{-1}$ than farmer's management. Water productivity increased from $0.35 \mathrm{~kg} \mathrm{~m}^{-3}$ to $0.65 \mathrm{~kg} \mathrm{~m}^{-3}$ in farmer's management to research management. Both the techniques are environment friendly for reducing groundwater use in the irrigated ecosystem. Considering water scarcity during dry months, cost of electricity and understanding all the benefits of AWD method and plastic pipe, farmers of the study area showed interest to adopt these technologies.

\section{REFERENCES}

Ahmed, K M, P Bhattacharya, M A Hassan, S H Akhter, S M M Alam, M A H Bhuyian, M B Imam, A A Khan and O Sracek. 2004. Arsenic enrichment in groundwater of the alluvial aquifers in Bangladesh: an overview. Appl. Geochem. 19:181-200.
Akkuzu, E, H B Unal and B S Karatas. 2006. Determination of water conveyance loss in the Menemen open canal irrigation network. Turkish Journal of Agriculture and Forestry, 31: 11-22.

Biswas, M R and M A S Mandal. 1993. Irrigation management for crop diversification in Bangladesh. Dhaka, Bangladesh: University Press Limited

Bouman, B A M, L Feng and T P Tuong. 2007. Exploring options to grow rice under water-short conditions in northern China using a modeling approach. Agric. Water Mgt. 88: 23-33.

Bouman, B A M, R M Lampayan and T P Toung. 2007. Water management in irrigated rice: coping with water scarcity. Los Banos (Philipines): International Rice Research Institute. p. 21.

BRRI (Bangladesh Rice Research Institute). 2007. Annual Report, 2006-07.

BRRI (Bangladesh Rice Research Institute). 2014. Annual Report, 2012-13. p. 292.

Geethalakshmi, V, T Ramesh, Azhagu Palamuthirsolai and A Lakshmanan. 2011. Agronomic evaluation of rice cultivation system for water and grain productivity. Archive of Agronomy and Soil Science. 57 (2): 159-166.

GoB (Government of Bangladesh). 2005. National strategy for accelerated poverty reduction. General Economics Division, Planning Commission and the Government of the People's Republic of Bangladesh

Huq, M A, M A T Ali, D K Das, Q Islam and A K M S Islam. 1992. Water lifting devices for irrigation in Bangladesh. Journal of Agriculture Mechanization of Asia Africa and Latin America. 23 (2):29

Khurmi, R S. 1997. A Textbook of Hydraulics, Fluid Mechanics and Hydraulic Machines. S. Chand and Company Ltd. Ramnagar, New Delhi. pp.196-197 
OECD (The Organization of Economic Co-operation and Development). 2010. Sustainable management of water resource in agriculture. ISBN 978-92-64083455.

Rashid, M A, A F M Saleh and L R Khan. 2005. Water saving and economics of alternate wetting and drying irrigation for rice. Bangladesh Journal of Water Resources Research. 20:81-93.

Satter, M A, N Hasan and D Roy. 2009. Annual progress report on dissemination of water management technologies in the farmer's field for increasing water productivity in rice based crop cultivation. BARC-BRRI.

Satter, M A. 2004. Irrigation principles and on-farm water management. Nandita prokash. P. 76.
Sayed, M A. 2010. Impact of lined canals on shallow tubewell irrigation and their acceptability by the farmers. Institute of Water and Flood Management. Bangladesh University of Engineering and Technology.

Tuong, T P and Bouman B A M. 2003. Rice production in water-scarce environments. International Rice Research Institute, Manila, Philippine. p. 54.

Uphoff, N. 2006. The system of rice intensification (SRI) as a methodology for reducing water requirements in irrigated rice production. International Dialogue on Rice and Water: Exploring Options for Food Security and Sustainable Environments. IRRI, Los Baños, Philippines. 